\title{
Effect of feeding turmeric on benzo(a)pyrene induced dominant lethal mutations
}

\author{
Nirmala Kota*, Virendra V. Panpatil ${ }^{\dagger}$, Vishnuvardhan Rao $\mathrm{M}^{\dagger}$ and Kalpagam Polasa ${ }^{\dagger}$ \\ *Correspondence: nirmala.nin@gmail.com \\ 'These authors contributed equally to this work. \\ National Institute of Nutrition, Jamai Osmania, Hyderabad, India.
}

\begin{abstract}
Background: Use of biomarkers particularly under in vivo condition is of importance in risk assessment. This study is proposed to identify the in vivo antigenotoxic potential using dominant lethal mutation test in B(a)P exposed, turmeric fed animals and evaluate the role of turmeric in counteracting the germ cell mutations.

Methods: Twenty four male mice were taken and divided into 4 groups each group containing 6 mice/group. The first and second group received stock diet (control) while the third and fourth groups received 5\% turmeric diet for a period of one month. At the end of feeding period, second and fourth group received a single dose of benzo(a)pyrene $1 \mathrm{mg} / \mathrm{mouse}$ intraperitoneally. After 1 week each male mouse was mated to 3 female mice at 1,4,8 and 12 week intervals. On $13^{\text {th }}$ day from mid point of mating, the females were sacrificed and live and dead embryos were counted to study the pre and post implantation loss of embryos. The differences in the frequencies of pre and post implant deaths were done by comparing treated with control group at 4-time periods by analysis of variance (ANOVA) and chi-square test which is used to compare treatment group and positive control with negative control.

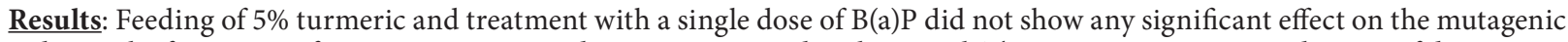
index or the frequency of pregnancy in treated groups compared with control. There was no apparent induction of dominant lethal mutations in $\mathrm{B}(\mathrm{a}) \mathrm{P}$ or $\mathrm{B}(\mathrm{a}) \mathrm{P}+$ Turmeric treated groups. No post implantation dominant lethal effects produced by $\mathrm{B}(\mathrm{a}) \mathrm{P}$ could be detected in this study. The induction of $\mathrm{B}(\mathrm{a}) \mathrm{P}$ and treatment with turmeric did not influence the dominant lethal test.

Conclusion: B(a)P did not produce a significant increase in the dominant lethal mutations. Turmeric also did not give any positive response and may be considered as non-mutagenic. The negative result suggests that under the conditions of the test the test substance may not be genotoxic in the germ cell of the treated sex of the test species.
\end{abstract}

Keywords: Turmeric, benzo(a)pyrene, mutations, dominant lethal assay

\section{Introduction}

DNA damage is a common feature of human spermatozoa with purported links to poor rates of conception, impaired embryonic development and increased incidence of miscarriage and the appearance of various kinds of morbidity in the offspring. Reactive oxygen species from various chemical carcinogens are known to play an important role in cell damage and in the development of cancer. Many free radical scavengers which are naturally occurring antioxidants have been found to be effective in inhibiting the induction of carcinogenesis by a wide variety of chemical carcinogens like benzo(a)pyrene $(B(a) P)$ which is a polycyclic aromatic hydrocarbon (PAH) and these hydrocarbons are mutagenic in somatic cells [1]. B(a)P is metabolized into BP diol epoxide that is able to bind to DNA and form bulky DNA adducts. Many studies have indicated that various spice principles are rich in anti oxidants. Turmeric belonging to the family zingiberaceae is used in Indian culinary and is an important spice crop having many medicinal properties. It is known that dietary substances like turmeric may also inhibit the genotoxic potential of some chemical carcinogens [2]. In addition a careful evaluation of possible toxicological and gentoxicological consequences for human health transplacental and transgeneration effects is necessary as humans will be largely exposed to potent inhibitors of carcinogenesis [3]. In particular it may be of much interest to evaluate the effect of turmeric towards $\mathrm{B}(\mathrm{a}) \mathrm{P}$ toxicity. This study is proposed to identify the in vivo antigenotoxic potential using dominant lethal mutation test in B(a)P exposed, turmeric fed animals and evaluate the role of turmeric in counteracting the germ cell mutations.

\section{Materials and methods}

Male and female Albino Swiss mice were obtained from the National Centre for Laboratory Animal Science (NCLAS) located in National Institute of Nutrition, Hyderabad and housed in the animal facility where the temperature was maintained at 24 $25^{\circ} \mathrm{C}$ with $12 \mathrm{~h}$ dark/light cycle. The experimental protocol was approved by the Institutional Animal Ethics Committee (IAEC) under the Committee for Purpose of Control and Supervision on Experiments on Animals (CPCSEA), Ministry of Environment and Forests, Government of India. Turmeric powder was obtained from commercially available standard grade (AGMARK). 
Kota et al. Journal of Genetics Study 2013,

http://www.hoajonline.com/journals/pdf/2054-1112-1-2.pdf

doi: 10.7243/2054-1112-1-2

Table 1. Frequency of pregnancy in females.

\begin{tabular}{|c|c|c|c|c|c|c|c|c|c|c|c|c|}
\hline \multirow[t]{2}{*}{ Week } & \multicolumn{3}{|c|}{ Control } & \multicolumn{3}{|c|}{ Turmeric (5\%) } & \multicolumn{3}{|c|}{$\mathbf{B}(\mathbf{a}) \mathbf{P}$} & \multicolumn{3}{|c|}{$\mathrm{B}(\mathrm{a}) \mathrm{P}+5 \%$ Turmeric } \\
\hline & $\begin{array}{c}\text { Total } \\
\text { females }\end{array}$ & $\begin{array}{l}\text { Pregnant } \\
\text { females }\end{array}$ & $\%$ & $\begin{array}{c}\text { Total } \\
\text { females }\end{array}$ & $\begin{array}{l}\text { Pregnant } \\
\text { females }\end{array}$ & $\%$ & $\begin{array}{c}\text { Total } \\
\text { females }\end{array}$ & $\begin{array}{c}\text { Pregnant } \\
\text { females }\end{array}$ & $\%$ & $\begin{array}{c}\text { Total } \\
\text { females }\end{array}$ & $\begin{array}{l}\text { Pregnant } \\
\text { females }\end{array}$ & $\%$ \\
\hline 1 & 18 & - & - & 18 & - & - & 18 & 2 & 11 & 18 & 4 & 22 \\
\hline 4 & 18 & 10 & 56 & 18 & 13 & 72 & 18 & 14 & 78 & 18 & 10 & 56 \\
\hline 8 & 18 & 11 & 61 & 18 & 15 & 83 & 18 & 12 & 67 & 18 & 15 & 83 \\
\hline 12 & 17 & 6 & 35 & 14 & 8 & 57 & 18 & 7 & 39 & 15 & 9 & 60 \\
\hline
\end{tabular}

Control vs Turmeric and other B(a)P treated groups -Not significant as analyzed by chi-square test and t-test

Table 2. Total dominant lethality in $\mathrm{B}(\mathrm{a}) \mathrm{P}$ induced mice treated with turmeric.

\begin{tabular}{|c|c|c|c|c|c|c|c|c|}
\hline \multicolumn{9}{|c|}{ Total implants ( Live+ Dead) } \\
\hline \multirow[t]{2}{*}{ Week } & \multicolumn{2}{|c|}{ Control } & \multicolumn{2}{|c|}{$5 \%$ turmeric } & \multicolumn{2}{|r|}{$\mathbf{B}(\mathbf{a}) \mathbf{P}$} & \multicolumn{2}{|c|}{$\mathrm{B}(\mathrm{a}) \mathrm{P}+5 \%$ turmeric } \\
\hline & $\begin{array}{c}\text { Total } \\
\text { implants }\end{array}$ & $\begin{array}{c}\text { Total } \\
\text { implants/female }\end{array}$ & $\begin{array}{c}\text { Total } \\
\text { implants }\end{array}$ & $\begin{array}{c}\text { Total } \\
\text { implants/female }\end{array}$ & $\begin{array}{c}\text { Total } \\
\text { implants }\end{array}$ & $\begin{array}{c}\text { Total } \\
\text { implants/female }\end{array}$ & $\begin{array}{c}\text { Total } \\
\text { implants }\end{array}$ & $\begin{array}{c}\text { Total } \\
\text { implants/female }\end{array}$ \\
\hline 1 & - & - & - & - & 28 & 1.56 & 38 & 2.11 \\
\hline 4 & 107 & 5.94 & 158 & 8.78 & 144 & 8.00 & 102 & 5.67 \\
\hline 8 & 114 & 6.33 & 160 & 8.89 & 144 & 8.00 & 165 & 9.17 \\
\hline 12 & 72 & 4.00 & 87 & 6.21 & 82 & 4.56 & 85 & 5.67 \\
\hline
\end{tabular}

Control vs Turmeric and other treated groups -Not significant as analyzed by chi-square test and t-test

\section{Study design}

Twenty four male mice were taken and divided into 4 groups each group containing 6 mice/group. The first and second group received stock diet (control) while the third and fourth groups received $5 \%$ turmeric diet for a period of one month. At the end of feeding period, second and fourth group received a single dose of benzo(a)pyrene $1 \mathrm{mg} /$ mouse intraperitoneally. After 1 week each male mouse was mated to 3 female mice at $1,4,8$ and 12 e week intervals. On $13^{\text {th }}$ day from mid point of mating, the females were sacrificed and live and dead embryos were counted to study the pre and post implantation loss of embryos. These studies were conducted in 6 males and 18 females. The same males were used for mating throughout experiment.

\section{Dominant lethal assay [4]}

Male mice were exposed to $B(a) P$ and were mated to untreated virgin female mice. The various germ cell stages were tested by the use of sequential mating intervals. The females were sacrificed after an appropriate period of time, and the contents of uteri were examined to determine the number of implants and live and dead embryos. The calculation of dominant lethal effect was based on comparison of the live implants per female in the treated group to the live implants per female in the control group. The increase of dead implants per female in the treated group over the dead implants per female in the control group reflected the post implantation loss. The post implantation loss was calculated by determining the ratio of dead to total implants from the treated group compared to the ratio of dead to total implants from the control group. Pre implantation loss was estimated on the basis of comparing the total implants per female in treated and control groups.

\section{Statistical analysis}

The differences in the frequencies of pre and post implant deaths were done by comparing treated with control group at 4-time period by analysis of variance (ANOVA) and chi-square test which is used to compare treatment group and positive control with negative control. The total number of implantations is evaluated by the Student's t-test to determine whether the average number of implantations per pregnant female for each treatment group and the positive control group differs significantly from the negative control group. Mutagenic effects were expressed conventionally as the mutagenic index (fetal deaths/total implants) X100.

\section{Results}

The statistical evaluations were based on the control values for each mating period. The results were tested to ascertain whether there was any dominant lethal effect. The dominant lethal effect in the experimental groups was calculated from the average number of live embryos obtained from the pregnant females as percentage of control. The numbers of living and dead implants were analyzed by chi-square test and to verify these results t-test was performed in which the rates of living implants in the control and treated groups were compared with one another. Frequency of pregnancy is represented in (Table 1 and 2), and was found to be not significant. No post-implantation dominant lethal effects produced by $\mathrm{B}(\mathrm{a}) \mathrm{P}$ could be detected in this study. The fraction 
Kota et al. Journal of Genetics Study 2013,

Table 3. Post implantation loss in $\mathrm{B}(\mathrm{a}) \mathrm{P}$ treated mice fed with turmeric.

\begin{tabular}{c|cccccccc}
\hline \multicolumn{7}{c}{ Post implantation (dead implants) } \\
\hline \multirow{2}{*}{ Week } & \multicolumn{2}{c}{ Control } & \multicolumn{2}{c}{$\mathbf{5 \% \text { turmeric }}$} & \multicolumn{2}{c}{ B(a)P } & \multicolumn{2}{c}{ B(a)P+5\% turmeric } \\
\cline { 2 - 9 } & $\begin{array}{c}\text { Total dead } \\
\text { implants }\end{array}$ & $\begin{array}{c}\text { Dead } \\
\text { implants/female }\end{array}$ & $\begin{array}{c}\text { Total dead } \\
\text { implants }\end{array}$ & $\begin{array}{c}\text { Dead } \\
\text { implants/female }\end{array}$ & $\begin{array}{c}\text { Total dead } \\
\text { implants }\end{array}$ & $\begin{array}{c}\text { Dead } \\
\text { implants/female }\end{array}$ & $\begin{array}{c}\text { Total dead } \\
\text { implants }\end{array}$ & $\begin{array}{c}\text { Dead } \\
\text { implants/female }\end{array}$ \\
\hline 1 & - & - & - & - & - & - & - & - \\
4 & 7 & 0.39 & 5 & 0.28 & 12 & 0.67 & 8 & 0.44 \\
8 & 4 & 0.22 & 4 & 0.22 & 5 & 0.28 & 12 & 0.67 \\
12 & 5 & 0.28 & 5 & 0.36 & 3 & 0.17 & 2 & 0.12 \\
\hline
\end{tabular}

Control vs Turmeric and other B(a)P treated groups -Not significant as analyzed by chi-square test and t-test

Table 4. Pre-implantation in $\mathrm{B}(\mathrm{a}) \mathrm{P}$ treated mice fed with turmeric.

\begin{tabular}{c|cccccccc}
\hline \multicolumn{7}{c}{ Pre- implantation (live implants) } \\
\hline \multirow{2}{*}{ Week } & \multicolumn{2}{c}{ Control } & \multicolumn{2}{c}{$\mathbf{5 \% \text { turmeric }}$} & \multicolumn{2}{c}{ B(a)P } & \multicolumn{2}{c}{ B(a)P+5\% turmeric } \\
\cline { 2 - 10 } & $\begin{array}{c}\text { Total live } \\
\text { implants }\end{array}$ & $\begin{array}{c}\text { Live } \\
\text { implants/female }\end{array}$ & $\begin{array}{c}\text { Total live } \\
\text { implants }\end{array}$ & $\begin{array}{c}\text { Live } \\
\text { implants/female }\end{array}$ & $\begin{array}{c}\text { Total Live } \\
\text { implants }\end{array}$ & $\begin{array}{c}\text { Live } \\
\text { implants/female }\end{array}$ & $\begin{array}{c}\text { Total live } \\
\text { implants }\end{array}$ & $\begin{array}{c}\text { Live } \\
\text { implants/female }\end{array}$ \\
\hline 1 & - & - & - & - & 28 & 1.56 & 38 & 2.11 \\
4 & 100 & 5.6 & 153 & 8.5 & 131 & 7.67 & 94 & 5.22 \\
8 & 110 & 6.1 & 156 & 8.7 & 139 & 7.28 & 153 & 8.50 \\
12 & 67 & 3.7 & 82 & 4.6 & 79 & 4.39 & 83 & 5.53 \\
\hline
\end{tabular}

Control vs Turmeric and other B(a)P treated groups -Not significant as analyzed by chi-square test and t-test

Table 5. Mutagenic index in B(a)P treated mice fed with turmeric.

\begin{tabular}{ccccc}
\hline \multicolumn{5}{c}{ Mutagenic index } \\
\hline Week & Control & 5\% turmeric & B(a)P & B(a)P+ 5\% turmeric \\
\hline 1 & - & - & - & - \\
4 & 6.54 & 9.02 & 3.16 & 7.84 \\
8 & 3.51 & 3.47 & 2.50 & 7.27 \\
12 & 6.94 & 3.65 & 5.75 & 2.35 \\
Mean & 5.66 & 5.38 & 3.79 & 5.80 \\
SD & 1.88 & 3.15 & 1.73 & 3.00 \\
SE & 1.08 & 1.82 & 0.99 & 1.74 \\
\hline
\end{tabular}

Control vs turmeric and other B(a)P treated groups-Not significant as analyzed by $\mathrm{t}$-test.

of dead embryos was not significantly different from control groups (Table 3). No significant pre-implantation losses were noted in either $\mathrm{B}(\mathrm{a}) \mathrm{P}$ or $\mathrm{B}(\mathrm{a}) \mathrm{P}+5 \%$ turmeric treated groups compared to control (Table 4). The mutagenic index compared between control versus turmeric and other $\mathrm{B}(\mathrm{a}) \mathrm{P}$ treated groups was not significant as analyzed by t-test (Table $\mathbf{5}$ ).

\section{Discussion}

The dominant lethal test in male is intended to detect mutagenic effects in the spermatogenic process that are lethal to embryos or fetus [5]. B(a)P has been shown to cause genotoxic effects in a broad range of prokaryotic and mammalian cell systems [6]. This study was taken up to evaluate dominant lethal mutation effects of turmeric in mice treated with a single dose of B(a)P $1 \mathrm{mg} /$ mouse. Extensive research has been carried out in NIN on turmeric, ginger, garlic etc. and has been demonstrated their antimutagenic effect using in vivo rat model $[7,8]$. Earlier reports showed that turmeric did not induce sex-chromosome loss and dominant lethal mutation did not occur when hot water extracts were administered to male drosophila [9]. A multigenerational study was conducted according to OECD testing guidelines using curcumin comprising $80 \%$. The authors reported that there were no treatment related clinical signs of toxicity or mortality during the premating period and there were no differences in gestational or post partum body weights in either generation. Curcumin was reportedly non-carcinogenic over three generations [10]. Govindarajan [11] reported that administration of curcumin into rats and rabbits at doses of 600 or $1600 \mathrm{mg} / \mathrm{kg}$ body weight did not show any effect on total implants, resorption, live and dead embryos and rats fed diet containing $0.5 \%$ turmeric or $0.015 \%$ curcumin for 12 weeks did not have any adverse effect on pregnancy rate, mean number of live and dead embryos. In another study incorporation of $0.5 \%$ turmeric or $0.015 \%$ curcumin in diets of mice did not show significant differences on the incidence of micronucleated PCE's, pregnancy rates and number of live and dead embryos, total implants and mutagenic index [12]. Other studies conducted on antimutagenicity of turmeric for a period of three months on 1, 3 and $5 \%$ turmeric in the diet and which received $\mathrm{B}(\mathrm{a}) \mathrm{P}$ on three occasions did not show any significant changes in any of the organs [13]. In one study multigenerational reproductive toxicity indicated that turmeric consumed at $500 \mathrm{mg} / \mathrm{kg}$ body weight or an alcoholic extract at $60 \mathrm{mg} / \mathrm{Kg}$ body weight per day did not affect the fertility index, gestational and lactation index and 
Kota et al. Journal of Genetics Study 2013,

no abnormal histological changes were recorded [14].

In this study feeding of 5\% turmeric and treatment with a single dose of $\mathrm{B}(\mathrm{a}) \mathrm{P}$ did not show any significant effect on the mutagenic index or the frequency of pregnancy in treated groups compared to control. There was no apparent induction of dominant lethal mutations in $\mathrm{B}(\mathrm{a}) \mathrm{P}$ or $\mathrm{B}(\mathrm{a}) \mathrm{P}+$ Turmeric treated groups. No post implantation dominant lethal effects produced by B(a)P could be detected in this study. The induction of $\mathrm{B}(\mathrm{a}) \mathrm{P}$ and treatment with turmeric did not influence the dominant lethal test.

\section{Conclusion}

$\mathrm{B}(\mathrm{a}) \mathrm{P}$ did not produce a significant increase in the dominant lethal mutations. Turmeric also did not give any positive response and may be considered as non-mutagenic. The negative result suggests that under the conditions of the test the test substance may not be genotoxic in the germ cell of the treated sex of the test species.

\section{Competing interests}

The authors declare that they have no competing interests.

\section{Authors' contributions}

\begin{tabular}{|l|c|c|c|c|}
\hline Authors' contributions & NK & VP & VR & KP \\
\hline Research concept and design & -- & -- & -- & $\sqrt{ }$ \\
\hline Collection and/or assembly of data & $\sqrt{ }$ & $\sqrt{ }$ & -- & -- \\
\hline Data analysis and interpretation & $\sqrt{ }$ & $\sqrt{ }$ & -- & $\sqrt{ }$ \\
\hline Writing the article & $\sqrt{ }$ & -- & -- & -- \\
\hline Critical revision of the article & $\sqrt{ }$ & $\sqrt{ }$ & -- & $\sqrt{ }$ \\
\hline Final approval of article & $\sqrt{ }$ & $\sqrt{ }$ & $\sqrt{ }$ & $\sqrt{ }$ \\
\hline Statistical analysis & -- & -- & $\sqrt{ }$ & $\sqrt{ }$ \\
\hline
\end{tabular}

Acknowledgement

The author wish to thank Mr. A.K. Rajakumar, NIN, for his technical help.

\section{Publication history}

Editor: Jimmy T. Efird, Brody School of Medicine, USA.

Received: 05-Sep-2013 Revised: 07-Oct-2013

Accepted: 22-Oct-2013 Published: 29-Oct-2013

\section{References}

1. Somers CM, McCarry BE, Malek F and Quinn JS. Reduction of particulate air pollution lowers the risk of heritable mutations in mice. Science. 2004; 304:1008-10. | Article | PubMed

2. Prasad $S$ and Aggarwal BB. Turmeric, the Golden Spice: From Traditional Medicine to Modern Medicine. 2011. I Article I PubMed

3. Autrup $\mathrm{H}$. Transplacental transfer of genotoxins and transplacental carcinogenesis. Environ Health Perspect. 1993; 101 Suppl 2:33-8. | Article | PubMed Abstract | PubMed Full Text

4. Epstein SS, Arnold E, Andrea J, Bass W and Bishop Y. Detection of chemical mutagens by the dominant lethal assay in the mouse. Toxicol Appl Pharmacol. 1972; 23:288-325. | Article | PubMed

5. Bateman AJ. Hand Book of Mutagenicity Test Procedures. In Kilbey BJ et al., (Eds.), Elsevier Amsterdam 1977; 235-334. I Book

6. USEPA. (U.S. Environmental Protection Agency). Human health evaluation manual, supplemental guidance: "Standard default exposure factors". OSWER Directive. March 1991, Washington.DC: Office of Emergency and Remedial Response, 9285.6-03. | Pdf

7. Kalpagam P, Annapurna VV, Prasanna Krishna T and Krishnaswamy K. Inhibitory effect of unprocesed/processed alliums under in vitro/in vivo conditions on carcinogen induced mutagenesis using different assays. Int J Cancer Res. 2006; 2:199-211. | Article

8. Nirmala K, Prasanna Krishna T and Polasa K. In vivo antimutagenic potential of Ginger on Formation and Excretion of Urinary Mutagens in Rats. Int J Cancer Res. 2007; 3:134-142. | Article

9. Abraham SK and Kesavan PC. Evaluation of possible mutagenicity of ginger, turmeric, asafetida, clove and cinnamon Administered Alone and in Combination With Caffeine or Theophylline in Drosophila Melanogaster. Mut. Res. 1978; 53:142. I Article

10. Ganiger S, Malleshappa HN, Krishnappa H, Rajashekhar G, Ramakrishna Rao $V$ and Sullivan $F$. A two generation reproductive toxicity study with curcumin, turmeric yellow, in Wistar rats. Food Chem Toxicol. 2007; 45:64-9. | Article | PubMed

11. Govindarajan VS. Turmeric--chemistry, technology, and quality. Crit Rev Food Sci Nutr. 1980; 12:199-301. I Article I PubMed

12. Vijayalaxmi. Genetic effects of turmeric and curcumin in mice and rats. Mutat Res. 1980; 79:125-32. | Article | PubMed

13. Polasa K, Sesikaran B, Krishna TP and Krishnaswamy K. Turmeric (Curcuma longa)-induced reduction in urinary mutagens. Food Chem Toxicol. 1991; 29:699-706. | Article | PubMed

14. Bhavani Shanker TN and Murthy VS. Reproductive response of rats fed turmeric (Curcuma Longa L.) and its alcoholic extract. J Food.Sci.Technol. 1987; 24:45-49. | Article

\section{Citation:}

Kota N, Panpatil VV, M VR and Polasa K. Effect of feeding turmeric on benzo(a)pyrene induced dominant lethal mutations. J Genet Stud. 2013; 1:2. http://dx.doi.org/10.7243/2054-1112-1-2 